University of Kragujevac

Kragujevac

GORDANA RADOVIĆ

Dnevnik-Poljoprivrednik AD Novi Sad

Novi Sad

ŽELJKO VOJINOVIĆ

University in Novi Sad

Novi Sad

\title{
SIGNIFICANCE OF THE SUSTAINABLE DEVELOPMENT OF RURAL TOURISM IN THE REPUBLIC OF SERBIA*
}

\begin{abstract}
The Republic of Serbia has all the necessary resources for the development of rural tourism, but it is insufficiently developed. According to the categorisation of the Organization for Economic Cooperation and Development (OECD), $85 \%$ of the Republic of Serbia's territory is rural. However, in accordance with the results of the Census of Agriculture in 2012, less than $1 \%$ of the total number of agricultural holdings is engaged in rural tourism. This paper's goal is to highlight the significance of rural tourism development in the Republic of Serbia based on the sustainability principles. The sustainable development of rural tourism is part of the integral rural development and it implies sustainable development from ecological, economic and social point of view. The sustainable development of rural tourism has a key significance for rural development and the decrease in local depopulation of rural areas in the Republic of Serbia. The authors consider as necessary to adopt the Strategy of Rural Tourism Sustainable Development as well as to define the method of management of sustainable development of rural tourism in the Republic of Serbia.
\end{abstract}

Keywords: rural tourism, sustainable development, strategy, Republic of Serbia.

JEL codes: O18, Z32, Q01.

\footnotetext{
* Paper is a part of research within the project no. 46006 III - Sustainable agriculture and rural development in the function of accomplishing strategic objectives of the Republic of Serbia in the Danube region, financed by the Ministry of Education, Science and Technological Development of the Republic of Serbia.
} 


\section{Introduction}

Rural tourism has started to develop more intensively during the 1970s, as part of the development strategies of rural areas. According to a definition of rural tourism, adopted in 1986 by the Council of Europe, which is nowadays accepted at the European Union level, rural tourism is a form of tourism encompassing all tourist activities which can be realised in rural areas. Put together, they make a tourist supply of rural areas. General features of rural tourism are direct communication and interaction between a tourist and a host (service provider), unspoiled environment without pollution and noise, catering facilities based on traditional food of a certain rural area, as well as the possibility for a tourist to take part in activities and a way of life of rural population. Significant factor of the attractiveness of a rural tourism product is cultural identity of a specific rural area, which comprises: "dressing culture, housing culture (it is important to preserve a traditional rural house, which preferably represents "a living" museum), spiritual, cultural, rural values (custom, mythical material, folklore, traditional and contemporary rural art)" (Cvijanović, 2014, pp. 28-29). The quality of direct communication between a guest and a host is also an important factor, which aims to reach the sustainable development of tourism in rural areas (Tucker, 2005).

Rural tourism is a multi-sector activity, taking into account the fact that tourist supply unites economic, social and cultural point of view. The manifestation of this form of tourism on the tourist market is connected to the specific requirements of tourists, which can be achieved in mass tourism opposite to personal experiences, and tourists who want to be informed about this form of tourism through different cultures, customs, habits, diet and lifestyle. These dissimilarities "can be realised the best in rural areas of specific countries, in regard that these areas represent the guardians of tradition, because no borders were erased concerning the characteristics of peoples and nations under the influence of mass culture" (Radović, Pejanović and Njegovan, 2012, p. 580).

Tourism is an indicator of the entire economic development, standards and one country's cultural development (Štetić, Cvijanović and Šimičević, 2014). Of the total number of tourists on the European market, in mid-1990s, $9 \%$ was interested in rural tourist areas, while in Great Britain around $25 \%$ of tourists was interested in rural tourism" (Cvijanović, 2014, p. 27). Rural tourism is today the most important economic and financial segment of tourist supply in many countries. It is estimated that rural tourists make up 3\% of the total number of tourists at the global level, and $25 \%$ in the European Union. This form of tourism records the annual growth of $6 \%$ at the global level, while the annual growth of total tourism is around 4\%. According to data provided by the European Federation for Rural Tourism (EuroGites), in 2014 there were around 500,000 accommodation units in Europe, or service providers in rural tourism, who had at their disposal over five million beds. In accordance with the current estimates, 
rural tourism generates around $15 \%$ of total tourist turnover on the territory of the European Union (Bartlet, 2006).

Diversification and development of rural economy, i.e. the development of rural areas on the sustainability principles and a multi-sector integral approach are some of the most important goals of the Common Agricultural Policy reform, defined by Agenda 2000. Agenda 2000, adopted in 1999, officially promotes the concept of multifunctional agriculture. This concept implies activities directed at ensuring additional incomes for rural population, development of rural areas as well as the preservation of environment and traditional rural values (cultural heritage, old crafts, traditional gastronomy, lifestyle, national customs and events).

Rural tourism can have both positive and negative effects on the environment and, therefore, it is inevitable to develop this form of tourism on a sustainable basis. "The development of rural tourism cannot be observed only as economic growth, but also from the aspect of ecological and social development" (George, Mair and Reid, 2009, p. 235). The sustainable development of rural tourism is part of the integral rural development, which is defined as a "modern concept which means the complex development of the specific rural area based on available natural, material, infrastructural and human resources, which are managed with proper respect regarding the preservation of balance between man and nature" (Njegovan and Pejanović, 2009, p. 180).

The development of tourism of the Republic of Serbia is not proportional to the resources it has at its disposal. According to the results of the Census of Agriculture in 2012, less than 1\% of agricultural holdings were engaged in rural tourism. Aiming to achieve the effective and efficient development of rural tourism in the Republic of Serbia, it is necessary to base it on a sustainable grounds, i.e. with proper respect to economic, ecological and social development factors. The goal of this paper is to point out the significance of rural tourism development in the Republic of Serbia on the basis of sustainability principles. The authors observe the rural tourism sustainability from the aspect of ecological, social and economic sustainability. This paper uses a method of analysis and synthesis, as well as an analytical SWOT analysis method.

\section{Sustainable development of rural tourism}

The sustainable development concept was adopted by the World Commission in 1987 (Brundtland Report) as the development method by which all current needs would be satisfied, without decreasing any possibility for the future generations to satisfy their own needs. In 1996, the World Tourist Organization (UNWTO) adopted Agenda 21 about the tourist economy. This document's goal was to help the authorities and entities in the field of tourism to realise their potentials in achieving the sustainable development at the local, regional, national and international level. Sustainable development is defined as balanced 
economic, social and cultural development, without jeopardizing the environment, which allows future generations to develop themselves through the use of resources at the same or even higher level.

In 2004, the Committee of World Tourist Organization (UNWTO) has decided to improve the sustainable tourism definition. A new conceptual definition puts emphasis on the balance among the ecological, social and economic aspects of tourism. The sustainable tourism should make optimal use of ecological resources, which make a key element of tourism development, maintaining the essential ecological processes and helping the natural heritage and biodiversity preservation. However, the development of sustainable tourism should respect the social and cultural authenticity of host communities, protect their established and contemporary cultural heritage and traditional values, and contribute to understanding and tolerance among cultures, as well as provide sustainable long-term business making social-economic benefits, which allocate fairly between all interest groups, including also stable employment (Milenković, 2009).

Tourist supply of rural areas must not jeopardize the environment, i.e. "the most attractive tourist destinations are the ones which have preserved physical-geographical environment, protected nature and anthropogenic tourist motives which attract tourists" (Štetić, 2007, p. 123). Rural tourism, as a selective form of tourism "gets its increasing significance in the context of ecological dimension of human and space and increasing awareness about the necessity of sustainable development" (Kosar and Rašeta, 2003, p. 40). Development of rural tourism should base on sustainable grounds. Development should be targeted to ensure the sustainable and adjusted development based on providing "the environment preservation, affirmation of social integrity, fostering cultural features of local population, optimal satisfaction of tourist needs and making an economic profit" (Jovičić, 2000, p. 27).

There is agreement among domestic (Čomić, 2003) and foreign authors (George et al., 2009) that the development of rural tourism cannot be seen only as economic growth, but it also has to be considered from the perspective of ecological and social development. Rural tourism and "especially tourism in an agricultural holding becomes more significant partner in sustainable development and human organisation of rural areas" (Kušen, 1995, p. 130). According to the quoted author, the development of rural tourism prevents disruption of the natural environment, affects the preservation of traditional national architecture, ethnographic elements, distinctive way of life and work, and it often provides the motive for infrastructural development, which contributes to the growth of other economic activities in rural areas.

Thus, the development of rural tourism on the sustainability principles should be directed at realisation of economic, ecological and socio-cultural goals. Economic goals imply economic growth, increase in employment and investments, 
and in ecological sense, the environmental preservation, the rational use of energy and prevention of aesthetic degradation of space. Socio-cultural goals comprise: increase in life quality, higher cultural and economic level, additional education, to be familiar with or to have a positive attitude towards other cultures, as well as fostering a local identity, protection of cultural monuments and developing the general safety (Pejanović and Đukić, 2011).

Due to the rate of consumption of natural resources, rural tourism should be based on adequate legislative provisions and strategic frameworks. The rate of natural resources consumption was analysed at the Summit on Sustainable Development, which was held in Johannesburg in 2002. At the Summit, it was stated that the rate of natural resources consumption is higher by $20 \%$ than the rate of their renewal. It was also anticipated that, if this dynamics continues, the ratio between consumption and renewal of natural resources will be exacerbated by 11 times until 2050 . Hence, many authors point out that "the development strategy of rural tourism should be based on ecological, economic and social sustainability" (Roberts and Hall, 2003, p. 6).

The development of rural tourism, based on sustainability principles, was mentioned also in the reform measures of Common Agricultural Policy, defined within Agenda 2000. The goal of the reform measures was to formulate alternative forms of employment and income resources for farmers, as well as to integrate ecological and structural aspects of Common Agricultural Policy. The European Union interest in multifunctional development of agriculture was emphasized, considering the fact that the goal of this development was not only the production of food, but also a constant raise in the food quality and safety, and also development of non-agricultural activities, rural development and the environmental preservation (Radović, 2009).

Modern approach to rural development is based on the integral rural development. The integral rural development is defined as a multi-sector concept, i.e. as an "integral, territorially rounded rural economy, consisting of a set of inter-connected economic activities and other activities connected to agribusiness" (Pejanović, Tica and Delić, 2005, p. 75). The integral rural development was supported also by the newest reform of the Common Agricultural Policy of the European Union for 2014-2020. Constant need for strengthening knowledge transfer in agriculture and competitiveness of all forms of agricultural production, was defined by the reform. The goals of the Common Agricultural Policy also included preservation and strengthening of ecosystem, efficient use of resources, promoting food chain, economic development of rural areas and the decrease of rural population poverty (http://ec.europa.eu/ agriculture/cap-post2013). 


\section{Significance of the sustainable development of rural tourism in the Republic of Serbia}

The Republic of Serbia has at its disposal all necessary resources for the development of rural tourism. Rural areas make $85 \%$ of the total territory of the country, i.e. 3,904 of the total of 4,715 settlements are rural and they are inhabited by over $50 \%$ of the total population. Comparative advantages for the development of rural tourism represent natural values, preserved rural architecture, diverse catering facilities, traditional hospitality, rich historical and cultural heritage as well as the attractive ethnic characteristics. The comparative advantages are necessary to valorise the destination on domestic and foreign tourist market through the concept of rural tourism sustainable development.

According to the Census of Agriculture in 2012, there were 631,122 agricultural holdings in the Republic of Serbia. Family agricultural holdings dominate and they make up $99.6 \%$ of the total number of registered holdings, while among them holdings with average size of up to two hectares are predominant (www.rzs.stat.gov.rs). These holdings cannot be competitive on the market of agricultural production, but they can develop non-agricultural activities. That is why "the rural tourism is a very important segment of multifunctional agriculture, whose development in the Republic of Serbia is the necessity, but also the development perspective" (Radović, Pejanović and Njegovan, 2011, p. 36).

Rural tourism is given priority in the Strategy of Tourism Development of the Republic of Serbia (Official Gazette of RS no. 91/2006) as regards the forms of tourism connected to special interests of tourists. At the moment, rural tourism is the most developed in AP Vojvodina, central and west Serbia. The development of rural tourism in other parts of the Republic is an imperative as well, because it is necessary to stop depopulation of rural areas, taking into account that every fourth village in Serbia was withering away. Unfavourable age structure is one of the basic characteristics of rural areas.

In the past poverty was and today it still is a great problem in rural areas. Around $14.2 \%$ of the total number of people living in rural areas was poor, and in urban areas $-7.8 \%$. Poverty is especially visible in south-east and partly west Serbia, where rural population makes up $25 \%$ of the total number of poor persons in the Republic (Bogdanov, 2007). At the end of 2009, Cvejić, Babović, Petrović, Bogdanov and Vuković (2011) conducted a research on the basis of which they concluded that every second agricultural producer lives below the poverty line, while in the population structure, according to the poverty degree, agricultural holdings make up even 54\%, non-agricultural - 34\%, and mixed holdings $-31 \%$. The cause lies in a fact that most of the rural residents have left without reliable incomes in the period of transition. Rural areas in the Republic of Serbia, besides low-productive and low-intensive agricultural production, are characterised also by high unemployment rate (over 20\%). According to the survey results, conducted in 2009 by the Ministry of Agriculture, Forestry and 
Water Management of the Republic of Serbia, the rural tourism employs on average two members of a household, and an average net monthly income from being engaged in rural tourism is around EUR 200 per household.

In accordance with data from the Tourism Association's archive in the Republic of Serbia, the rural tourism has started to develop during the 1970s, when 50 villages have been engaged in rural tourism, i.e. around 800 households, which had 3,000 beds (Muhi, 2009). In 2009, according to official data 145,354 registered overnight stays were noted in rural tourism in the narrow sense, and $2,700.000$ or $27 \%$ of the total number of overnight stays were noted on the territory of the Republic in all forms of tourism.

There are no official data on the number of registered agricultural households which are engaged in rural tourism. According to the assessment of the local tourist organizations, mentioned in the Developmental Programme of Sustainable Rural Tourism (Official Gazette of RS, no. 85/2011), the Republic of Serbia has 10,567 beds in rural households and it is assumed that there are 32,747 beds more that could still be used for the rural tourism needs. It is assessed that RSD 10 milliard of income from rural tourism was realised in 2010 , or $16 \%$ of total RSD 62 milliard, which is the total direct tourist gross domestic product for Serbia in 2010. According to the results presented in the Programme of Sustainable Tourism Development, the rural tourism is characterised by great seasonal variations regarding tourist visits and very low average occupancy of accommodation capacities (only 4\%), while in other fields of tourism it is $21 \%$.

Rural areas are characterised by great differences regarding natural, infrastructural and other conditions for agricultural production, as well as for development of other economic activities. This differentiation becomes apparent also in regard to the economic and social development, demographic characteristics and trends, cultural peculiarities, size and morphology of settlements, which, put together, affect the efficiency of economy and life quality. Multifunctional agriculture dominates in rural areas, so Serbia is considered as the most agrarian country in Europe.

Perceiving the possibilities, i.e. the comparative advantages for the development of rural tourism, as well as the current level of poverty and underdevelopment of rural areas, we point out the significance of rural tourism development in the Republic of Serbia. It is necessary for the rural tourism development "to be observed as multi-sector, based on an adequate legal and strategic framework, as well as on the principles of ecological, social, cultural and economic sustainability" (Cvijanović, Radović and Cvijanović, 2016). Taking into consideration that one monetary unit invested in tourism brings income up to 2.2 monetary units, farms and also the local economy would benefit from rural tourism development. "Strong strategic and financial support of the state" (Pejanović and Radović, 2012, p. 16) is necessary in order to develop this form of tourism contributing the most to the rural economy diversification and the development of multifunctional agriculture. 


\section{Research results}

Sustainable development of rural tourism in the Republic of Serbia must be analysed by SWOT analysis, which is compulsory in the methodology for making the rural developmental programme. "SWOT analysis is an analytical method which reveals organisational strengths, weaknesses, chances and threats. It means that this method reveals the internal and external characteristics, in order to use own advantages as best as possible and to correct deficiencies, and accordingly form an adequate strategy for improving the competitive position and enable the realisation of best business results" (Čerović, 2002, p. 111).

Aiming to perceive advantages, weaknesses, chances and limits for the sustainable development of rural tourism, data from the available literature were used, as well as the results of a survey which included over 100 entities of rural tourism on the territory of the Republic of Serbia. The authors were analysing the rural tourism sustainability from the ecological, economic and social point of view.

\section{Advantages for the sustainable development of rural tourism in the Republic of Serbia}

The primary advantage for the rural tourism sustainable development in the Republic of Serbia is dominant rurality of this territory (85\%), according to the categorisation of the Organization for Economic Cooperation and Development. The dominant advantage is that these areas are populated by more than half of the total number of inhabitants, who could be potentially engaged in rural tourism and related activities.

According to criteria of the International Union for Conservation of Nature (IUCN), the Republic of Serbia's territory is one of six European and 153 world centres of biological diversity, and the surface of protected areas in Serbia makes up $6.5 \%$ of total territory. There are 428 protected animal and 215 plant species in the Republic of Serbia. There are also 1,300 protected nature objects, of which 5 are national parks, 22 - regional parks, 122 - nature reserves and 375 - natural monuments (Štetić, 2007).

Rural areas are characterised by the traditional hospitality of its residents, as well as traditional social values (a sense of togetherness, local culture and lifestyle, life in harmony with nature, etc.). Rural areas are also characterised by their natural beauties, unspoiled environment, rich cultural heritage, preserved traditional architecture, old crafts as well as the tradition in making wristwatches.

Over 1,500 different tourist events are organised in the Republic of Serbia per year and they are a result of the rural population creativity. Gastronomic and ethnographic events are dominant. It is necessary to connect several ethnographic or gastronomic events in a sense of time and territory and provide accommodation in rural households to guests in the vicinity of a locality where 
these events are held. "In order to highlight the originality of a certain locality, it is necessary to avoid the organisation of similar events in different places, and to keep organising this event, characteristic for that area" (Radović, Pejanović, Njegovan and Košić, 2012, p. 703).

\section{Weaknesses of the sustainable development of rural tourism in the Republic of Serbia}

No strategic decision in the Republic of Serbia was made that tourism, i.e. rural tourism, is one of the basic strategic directions of economic development. This economic activity is not considered as one of export priorities, although it realises a significant foreign currency income. There is no institution which would continuously and methodologically manage rural tourism sustainable development. Therefore in the current period, the rural tourism is insufficiently organised, which disables adequate valorisation of tourist resources in the Republic of Serbia. It is also characterised by a lack of financial resources for investments in the rural tourism development, at micro and macro levels.

Another shortage in the field of development of rural tourism on a sustainable basis is the lack of standards in rural tourism. Because of this quality of services is uneven and incomes in rural tourism are lower. Although it should officially exist, there is no registry of service providers in practice. The level of cooperation between service providers is insufficient, which weakens their negotiating power with state and financial institutions.

Underdeveloped rural infrastructure (transport and municipal) and tourist signalisation, lack of accommodation capacities and tourist contents, poor promotion of rural tourist products and insufficient interest of tourist agencies for its sale are the significant weaknesses of rural tourism sustainable development in the Republic of Serbia. Insufficient training of service providers is also a problem, and it is very important because rural tourism is characterised by interaction between a guest and a host. Hygiene conditions are often very bad in rural areas, as well as the ecological awareness of rural population.

\section{Chances for the sustainable development of rural tourism in the Republic of Serbia}

Significant chance for the sustainable development of rural tourism is the increasing need of urban population for fast vacations in rural areas. It is a chance for the rural tourism development, but also for the sale of agricultural products' surpluses "at a market in one's own backyard". In that way, the chances for gaining an additional income from rural tourism increase also for those people who have no accommodation capacities, but who now have the possibility to sell processed agricultural products, home craft products, old craft products, etc. All of this would enable revitalisation of villages, increase in income at the local level and immigration of population from urban areas. 
The chance for the rural tourism sustainable development is also present in the diffuse hotels development, which would enable joining forces by service providers, but it would also provide all necessary accommodation capacities in some villages. To be more specific, in villages where today, it is not possible to accommodate 50 tourists (one tourist bus).

It is necessary to better use numerous protected areas and natural reserves in the Republic of Serbia in order to achieve the sustainable development of rural tourism. Therefore, it is necessary to "build educational centres for visitors, whose basic function would be the promotion of protected areas, education, but also the exchange of information and experiences" (Radović, Njegovan and Cvijanović, 2011, p. 329). In these centres tourists could get information on the accommodation possibilities in rural tourist households in the vicinity, which would provide also the increase in income from rural tourism and its sustainable development.

There are possibilities for the rural tourism development on a sustainable basis in integral rural tourist products which would unite several forms of rural tourism. In order to develop, it is also inevitable to conduct the strong promotion, planned sales of a rural tourist product, as well as the use of modern forms of communication, i.e. the information technologies.

\section{Constraints for the sustainable development of rural tourism in the Republic of Serbia}

The most important constraint for the sustainable development of rural tourism in the Republic of Serbia is depopulation of villages. Another limitation is also commercialisation of rural areas and making local "turbo heritage and culture", atypical for certain area. The limitation for the sustainable development of rural tourism is also inadequate care for the environment, and increase in environmental problems due to increased strain on using rural space in the development of tourism.

The limitations for the rural tourism sustainable development are also insufficient incomes of service providers, which make them unable to invest, as well as the insufficient occupancy of accommodation capacities, due to the lack of free time or reduced financial solvency of population in urban areas (phenomenon of the disappearance of the middle class). The limitation for the rural tourism sustainable development can be represented also by the resistance of the local population towards the development of rural tourism, owing to the increase in the cost of living, caused by its development.

\section{Conclusion}

Although the Republic of Serbia has the necessary resources, it does not have the adequate development level of rural tourism. It is necessary to see the development of rural tourism as multi-sector in the future, as well as to develop it 
on a sustainable basis. The sustainable development of rural tourism represents a part of the integral rural development and it implies sustainable development from the ecological, economic and social perspective.

The sustainable development of rural tourism has a key significance for rural development, as well as the decrease in the local depopulation in the Republic of Serbia and poverty of rural population. That is why, it is inevitable to adopt the Strategy of Rural Tourism Sustainable Development. All advantages and chances for the rural tourism sustainable development must be included in this document, and it has to cover the issues of provision of financing for sustainable development of rural tourism, provided that this activity comprises and brings together numerous subjects, which need to be synchronised and implemented according to a plan. It is also necessary to define standards and increase the quality of services in rural tourism. This is the only way to ensure the increase of income from rural tourism, the development of rural economies and the decrease of regional dissimilarities in economic development in the Republic of Serbia. 


\section{References}

Bartlet, T. (2006). Rural Tourism development in Europa. International Forum on Rural Tourism. China, 4-6. September 2006. Final Report World Tourism Organization.

Bogdanov, N. (2007). Mala ruralna domaćinstva u Srbiji i ruralna nepoljoprivredna ekonomija. Beograd: MPŠV RS, UNDP.

Cvejić, S., Babović, M., Petrović, M., Bogdanov, N., Vuković, O. (2011). Rezultati istraživanja nevladine organizacije SEConS. Socijalna isključenost u ruralnim oblastima Srbije. Beograd: UNDP.

Cvijanović, D. (2014). Turističko tržište u Dunavskom regionu. Monografija. Institut za ekonomiku poljoprivrede, Beograd.

Cvijanović, D., Radović, G., Cvijanović, G. (2016). Resources and the Rural Tourism Development in the Republic of Serbia. In the Book of Abstracts, XIII International Scientific Conference on Service sector INSCOSES 2016, Ohrid, 06-07 October 2016, p. 17 (the manuscript is in the process of publication).

Čerović, S. (2002). Strategijski menadžment turističke privrede Srbije. Želnid, Beograd.

Čomić, Đ. (2003). Prostorno-planski modeli razmeštaja turizma u ruralnoj sredini. Zbornik radova. Drugi Forum: Ruralni turizam i održivi razvoj Balkana, Kragujevac, 07-09. maj 2003. godine.

George, W., Mair, H., Reid, D. (2009). Rural tourism Development Localism and Cultural Change. Toronto: Channel view Publications.

Jovičić, D. (2000). Turizam i životna sredina - koncepcija održivog turizma. Beograd: Zadužbina Adrejević.

Kosar, Lj., Rašeta, S. (2003). Ocena mogućnosti primene menadžmenta kvaliteta u ruralnoj sredin. Zbornik radova, Drugi Forum: Ruralni turizam i održivi razvoj Balkana, Kragujevac, 07-09. maj 2003. godine.

Kušen, E. (1995). Turizam na seljačkom gospodarstvu. Naučno-stručni časopis: Turizam, godina XLIII, broj 7-8/1995. Zagreb: Hrvatska turistička zajednica, Institut za turizam.

Milenković, S. (2009). Turizam i ekonomija. Kragujevac: Univerzitet u Kragujevcu, Ekonomski fakultet.

Muhi, B. (2009). Primena marketinga u seoskom turizmu Vojvodine. Sremska Kamenica: Univerzitet Edukons, Fakultet poslovne ekonomije.

Njegovan, Z., Pejanović, R. (2009). Ruralna regionalizacija AP Vojvodine. Monografija, Novi Sad: Poljoprivredni fakultet.

Official Gazette of RS no. 91/2006.

Official Gazette of RS no. 85/2011.

Pejanović, R., Tica, N., Delić, S. (2005). Agrarno preduzetništvo. Tematski zbornik, Međunarodni naučni skup: Multifunkcionalna poljoprivreda i ruralni razvoj, Beograd, 8-9. decembar 2005. godine.

Pejanović, R., Đukić, S. (2011). Master plan održivog razvoja Fruške gore sa naglaskom na ekološke segmente, turizam i organsku proizvodnju. Peti formu o organskoj proizvodnji, Selenča.

Pejanović, R., Radović, G. (2012). Rural tourism as a factor of rural economy diversification in the Republic of Serbia. W: Thematic Proceedings, International Scientific Conference „Sustainable Agriculture and Rural Development in Terms of the Republic of Serbia Strategic Goals Implementation within Danube Region-preservation of rural values", Institut za ekonomiku poljoprivrede, Beograd, Tara, December, 6-8, 2012, pp. 1-17. 
Programu razvoja održivog ruralnog turizma u Republici Srbiji. Službeni glasnik RS br. $85 / 2011$.

Roberts, L., Hall, D. (2003). Rural Tourism and Recreation: Principles to Practise. Oxon, UK: CABI Publishing.

Radović, G. (2009). Magistarska teza: Modaliteti finansiranja agrara u tranzicionom perio$d u$. Subotica: Univerzitet u Novom Sadu, Ekonomski fakultet.

Radović, G., Pejanović, R., Njegovan,Z. (2011). Ruralni turizam-faktor razvoja multifunkcionalne poljoprivrede u Republici Srbiji. Zbornik apstrakata, Naučni skup, Savremeni trendovi u evropskoj ekonomiji: implikacije za Srbiju, Visoka Poslovna 마ola strukovnih studija, Novi Sad, 27. oktobar 2011. godine, p. 36.

Radović, G., Njegovan, Z., Cvijanović, D. (2011). Razvoj agro-eko turizma u zaštićenim područjima APV i prekogranična saradnja. Ekonomika poljoprivrede, Specijalni broj 1, Knjiga II, God./Vol. LVIII; p. 325-330.

Radović, G., Pejanović, R., Njegovan, Z. (2012). Značaj i uloga integrisanog ruralnog turističkog proizvoda u Republici Srbiji. Ekonomski vidici - tematski broj: Privredni preobražaj Srbije - mogućnosti i ograničenja, Vrdnik, 06-07. decembar 2012.godine, DruØtvo ekonomista Beograda, Godina XVII, Broj 4, UDK-33, pp. 577-591.

Radović, G., Pejanović, R., Njegovan, Z., Košić, K. (2012). Event tourism as a potential generator of development of the rural tourism in the Republic of Serbia. W: Book of proceedings, Third International Scientific Symposium: „AGROSYM 2012“, Jahorina, November 15-17., 2012., pp. 698-704.

Strategija razvoja turizma Republike Srbije. Službeni glasnik RS br.91/2006.

Tucker, H. (2005). The Host-Guest Relationship and its Implications in Rural Tourism, in New Directions in Rural Tourism. D. Hall, L. Roberts, M. Mitchell (red.), Ashgate Publishing Limited, Aldershot, England, p. 87.

Štetić, S. (2007). Posebni oblici turizma. Beograd.

Štetić, S., Cvijanović D., Šimičević D. (2014). Posebni oblici turizma Dunavskog regiona Srbije. Monografija, Beograd: Institut za ekonomiku poljoprivrede.

http://ec .europa.eu/agriculture/cap-post2013 (sajtu pristupljeno - oktobar 2016).

http://www.rzs.stat.gov.rs. (sajtu pristupljeno - novembar 2016). 
DRAGO CVIJANOVIĆ

Uniwersytet w Kragujevacu

Kragujevac

GORDANA RADOVIĆ

Dnevnik-Poljoprivrednik, AD Nowy Sad

Nowy Sad

ŽELJKO VOJINOVIĆ

Uniwersytet w Nowym Sadzie

Nowy Sad

\title{
ZNACZENIE ZRÓWNOWAŻONEGO ROZWOJU TURYSTYKI WIEJSKIEJ W REPUBLICE SERBII
}

\begin{abstract}
Abstrakt
Republika Serbska ma wszelkie zasoby niezbędne do rozwoju agroturystki, jednak sam kraj jest niewystarczajaco rozwinięty. Wedtug kategoryzacji Organizacji Wspótpracy Gospodarczej i Rozwoju (OECD) 85\% obszaru Serbii to obszary wiejskie. Jednak zgodnie z wynikami Spisu rolnego z 2012 r. mniej niz 1\% wszystkich gospodarstw rolnych zajmuje sie agroturystyka. Celem niniejszego artykułu jest podkreślenie znaczenia rozwoju agroturystyki w Serbii zgodnie z zasadami zrównoważonego rozwoju. Zrównoważony rozwój agroturystyki stanowi część całościowego rozwoju obszarów wiejskich i implikuje zrównoważony rozwój z ekologicznego, gospodarczego i społecznego punktu widzenia. Zrównoważony rozwój agroturystyki ma kluczowe znaczenie dla rozwoju obszarów wiejskich i zmniejszenia lokalnej depopulacji obszarów wiejskich w Serbii. Autorzy uznaja, że konieczne jest przyjęcie Strategii Zrównoważonego Rozwoju Agroturystyki, a także określenie sposobu zarzadzania zrównoważonym rozwojem agroturystyki $w$ Serbii.
\end{abstract}

Słowa kluczowe: agroturystyka, zrównoważony rozwój, strategia, Serbia.

Accepted for print: 20.06 .2017$.

Unless stated otherwise all the materials on the website are available under the Creative Commons Attribution 3.0 Poland license. Some rights reserved to the Institute of Agricultural and Food Economics - National Research Institute.

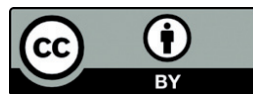

